\title{
The Influence of Leadership Style on the Performance of Educators and Educational Staff at the Faculty of FTIK, IAIN Bukittinggi
}

\author{
Sulaiman ${ }^{*}$, Aniswita ${ }^{2}$, Nurhizrah Gistituati ${ }^{3}$, Rusdinal ${ }^{4}$ \\ 1,2,3,4Universitas Negeri Padang, Padang, Indonesia \\ 1*sulaimanarrasyid@gmail.com, ${ }^{2}$ aniswitaumar@gmail.com, ${ }^{3}$ rusdinal@fip.unp.ac.id, \\ ${ }^{4}$ gistituatinurhizrah@gmail.com
}

\begin{abstract}
Article Info
History of the article

Received June 28, 2021

Revised September 20, 2021

Accepted November 2, 2021

Keywords: Influence,

Leadership Style; Performance;

ABSTRACT

The purpose of this study was to examine the effect of leadership style on the performance of educators and education staff at the Faculty of Tarbiyah and Teacher Training (FTIK) IAIN Bukittinggi. The population in this study were all educators and education staff at the FTIK IAIN Bukittinggi, totaling 75 people and 37 people randomly selected. Data were collected using questionnaires, leadership style questionnaires, and performance points. The data collected was processed using regression analysis. Researchers use the help of SPSS software. The results showed that the regression model formed was $Y=180,638+0.398 X$ with a $23.3 \%$ influence contribution. Based on the results of hypothesis testing, a significance value of $0.003<0.05$ was obtained. Based on the research that has been done, there is the performance of the teaching and educational staff of FTIK IAIN Bukittinggi in the excellent category. The ability of educators and education staff of FTIK IAIN Bukittinggi in achieving work results at the stipulated time is one indicator of the success of the FTIK IAIN Bukittinggi leadership in leading. A leader is also essential to provide encouragement or work motivation to employees or their subordinates to perform as proactive and successful employees.
\end{abstract}

\section{INTRODUCTION}

Universities have a very strategic function in managing education with three major scopes: Teaching Universities, Research Universities, and the University as a bastion of Civilization (Bastion of Civilization). As stated in Law number 12 of 2012 concerning Higher Education, Article 58 states that the Functions and Roles of Higher Education are: (1) as a forum for student and community learning; (2) as a forum for educating the nation's leaders; (3) as a center for the development of science and technology; (4) as a center for the study of virtue and moral strength to seek and find the truth; and (5) as a center for the development of the nation's civilization.

Every college wants its members to have high performance. It is an ideal goal for every university that is oriented to the desired results, and because it is the ideal goal of every university that is oriented to optimal results, because how is it possible for a university to get optimal results if it is not filled by people inside productive people who in this case are called educators and education staff. As stated from the study results (Kebede \& Demeke, 2017) with 
findings that show there is a positive influence of leadership on job satisfaction of staff and subordinates at the university. The style and behavior of the leader influence increasing awareness, job satisfaction, and organizational effectiveness at the university. Therefore, a leader's leadership style at a university is very influential on the performance of educators and education staff.

Furthermore, in higher education management, there is the interaction between the leadership and members to provide instructions and delegate the tasks to be carried out. According to Tampubolon (2007), leadership style is behavior and strategy, resulting from a combination of philosophy, skills, traits, attitudes, which are often applied by a leader when he tries to influence the performance of his subordinates. In the context of higher education organizations, an employee or educator and education staff is said to have a good performance if the educator and education staff can achieve and have work results that are more than the standard or the same as the criteria that have been jointly determined in the institution.

Then, In line with that, Sudarmanto (2009) also mentions that the success of an organization is seen from the individuals within it who work effectively and achieve optimal results. So it means that if an employee in a higher education institution achieves good performance, it will have an impact on the effectiveness or success of the institution in achieving its goals.

In achieving the vision and mission of the institution, the existence of a positive organizational culture will accelerate the achievement of the goals of higher education that are set, as a weak or negative organizational culture also causes obstacles in achieving higher education goals. A strong organizational culture will create a shared vision that will affect the understanding of the institutional values to be fought for together. Once these values are understood in-depth, it is believed that all or most of the institution members (academic staff and higher education staff). Then it was confirmed that a strong and positive culture greatly influences the behavior and effectiveness of higher education performance (Kadir, 2013).

Next, as evidence of effective leadership, one of them is shown by the ability to provide direction or instructions to members (educators and education staff) how members can adapt to various problem-solving methods used by prioritizing ways of thinking, feeling, and acting appropriately and related to solving the problems encountered. So with such a leadership style, it is assumed that the leadership has shown its performance in a positive and influential way to members, especially new members, as a way to provide direction/instructions to new members so that they have clear perceptions, thoughtful ways of thinking and can feel various urgent matters. To be carried out in the stages of problem-solving at the institution where they work. Another factor that must be considered in managing tertiary institutions is how the existing leadership system can maintain and improve the performance of educators and education personnel, namely by increasing the quality of service to clients or the community 
of universities as indicated by the level of satisfaction in receiving learning services, academic, bureaucratic services. And service to the general public.

Furthermore, as evidence of the job satisfaction of the members of the Institute, it is shown by the achievement of work supported by good work morale and high discipline. Besides that, job satisfaction is also shown by a balanced combination of working in the context of work and contexts outside of work or a combination of doing work that is directly related or not directly related. This will be seen in the positive attitudes of educators and education staff that appear or appear when they work and when they do everything related to their work. Then the positive attitude of educators and education staff will positively impact the quality of work and be able to create a positive climate in the environment where they work.

The purpose of this research is to discuss and at the same time describe how the relationship and influence between the leadership style of the institution and the performance of educators and education personnel in the context of managing higher education institutions are.

\section{METHOD}

This research is quantitative research with the type of research used is correlational research. Correlational research aims to determine the relationship and level of relationship between two or more variables without any attempt to influence these variables so that there is no manipulation of the variables (Fraenkel \& Wellen, 2008). Added by Gay in Emsir (2009), the purpose of correlational research is to find relationships and be used to make predictions so that one type of correlational research is predictive research or regression research.

This type of correlation research focuses on measuring one or more variables that can be used to predict or predict future events or other variables (Borg \& Gall in Abidin, 2010). The relationship in this study is causal; that is, one variable affects the other. Based on the research objective to examine the influence of leadership style on the performance of educators and education staff at FTIK IAIN Bukittinggi, it can be concluded that this type of research is predictive correlation research.

This research was conducted at the Tarbiyah and Teacher Training Faculty (FTIK) IAIN Bukittinggi. The object that will be used in this research is the Faculty of Education IImu, State Islamic Institute of Religion, Bukittinggi, with instruments in the form of a questionnaire covering the faculty's leadership style and a performance questionnaire of educators FTIK IAIN Bukittinggi education staff.

The population is all teaching and academic staff of FTIK, totaling 75 people. The number of samples in this study which was taken, was determined as much as 50 percent of the population so that a sample of 37 people were obtained. The sampling technique used is simple random sampling, which is a random sampling technique without regard to the existing 
strata in the population. The instrument used to collect data is a questionnaire, namely a leadership style questionnaire and a performance questionnaire. It was then analyzed using regression analysis with the help of SPSS V.22 software.

\section{RESULTS AND DISCUSSION}

\subsection{RESEARCH RESULT}

The results and discussion of the research will be described in this section, where after carrying out the research stages, the results of the research are obtained, and further discussion is carried out related to the influence of leadership style on the performance of educators and education staff at FTIK IAIN Bukittinggi.

The collected data were processed using the help of SPSS. Prior to the regression analysis, it was investigated whether the data met the regression analysis requirements: regular and linear. From the analysis for norms, the significance values for leadership style and performance were 0.197 and $0.077>0.05$, respectively. Based on these results, it can be concluded that the two data groups are normally distributed. For linearity, a significance value of $0.829>0.05$ was obtained. Based on these results, it can be concluded that the data relationship is linear.

The two prerequisites for the regression analysis were met, then the hypothesis was tested with the statistical hypothesis as follows:

HO: There is no significant effect of leadership style on the performance of educators and education staff at FTIK IAIN Bukittinggi

$\mathrm{H1}$ : There is a significant influence of leadership style on the performance of educators and education staff at FTIK IAIN Bukittinggi.

From the results of the analysis, the regression model of leadership style on the performance of educators and education staff at FTIK IAIN Bukittinggi is obtained, namely, $\hat{Y}=180.638+0.398 \mathrm{X}$, meaning that the performance of educators and education personnel can be predicted from the leadership style by using the above equation or model.

The results of the regression test can also be related to the leadership identity problem, which is not only determined by the behavioral attributes of a leader and the effectiveness of the way he leads, such as the ability to build relationships, communication skills, motivation for performance, and response to changes in workplace dynamics but the identity as well. It can come from employees' perceptions of their leadership style. Regarding leadership identity, Yeo (2020) mentions that a situation or situation, along with other people's perceptions, can also shape and give a stigma or leadership identity to a leader of an institution, which can become the identity (style) of leadership.

To test the hypothesis or the significance of the regression model, I used the F test with SPSS output, as shown in Table 1. 
Table 1. Hypothesis test

\begin{tabular}{|c|c|c|c|c|c|c|}
\hline \multicolumn{7}{|c|}{ ANOVA $^{a}$} \\
\hline Model & & $\begin{array}{l}\text { Sum of } \\
\text { Squares }\end{array}$ & df & Mean Square & $\mathrm{F}$ & Sig. \\
\hline \multirow[t]{3}{*}{1} & Regression & 1103.365 & 1 & 1103.365 & 10.307 & $.003^{\mathrm{b}}$ \\
\hline & Residual & 3639.635 & 34 & 107.048 & & \\
\hline & Total & 4743.000 & 35 & & & \\
\hline
\end{tabular}

a. Dependent Variable: Kinerja

b. Predictors: (Constant), Kepemimpinan

From Table 1, it can be seen that the significance value is $0.003<0.05$. So it can be concluded that reject $\mathrm{HO}$ and accept $\mathrm{HI}$ or there is a significant influence of leadership style on the performance of educators and education staff at FTIK IAIN Bukittinggi. The magnitude of the contribution or influence is $23.3 \%$; in other words, the leadership style can explain $23.3 \%$ of educators' and education performance.

\subsection{DISCUSSION}

Based on the research results, it can be seen that leadership style has a relationship and affects performance as the concept of leadership has been standardized and becomes the basis of reference in managing an organization, especially in higher education institutions which incidentally are educational or teaching institutions. In this organization (institution), the emphasis is on shaping the behavior of the academic community as a priority for the programs being carried out. It is in line with the concept of competence in education itself which includes three domains, namely cognitive, affective and psychomotor. Thus, a leader's leadership style in an educational institution is also an example for the members he leads.

In general, when carrying out their leadership roles, leaders choose how they position themselves to elicit the desired response from their employees. Also explained by Yeo (2020) that a leader can project a personal or authoritative voice when dealing with others depending on their priorities or concerns. For example, a leader is a person who is often seen as authoritative in times of crisis or urgency when rational normative considerations can no longer be carried out usually. Meanwhile, on other occasions, a leader can do some intermezzo to harmonize/meltdown the atmosphere and interact in a friendly or relaxed manner with his relations. However, it is still done in the context of prioritizing the institution's interests.

This article aims to determine the analysis results in describing the influence of leadership style on the performance of educators and education staff of FTIK IAIN Bukittingggi. It needs to be done considering the importance of the quality of higher education leadership in making and delivering policies in institutions to improve the performance of educators and education 
staff so that they can create changes and improve the quality of organizational policies. (Raffo \& Gunter, 2008). Likewise, higher education institutions have diverse academic communities, ranging from employees, employees, students, lecturers, etc.

The observations also found cases of passive leadership, observed from the side of its negative significance on extra effort and effectiveness and the presence of job dissatisfaction. It implies that a leader's indifference does not satisfy employees in any way whatsoever. Regarding this matter, King and Palanichamy (2011) Explaining Transactional Leadership has no significant predictability in Extra Effort, Effectiveness, or Satisfaction levels. However, when one of the Transactional Leadership sub-scales (i.e., Management with Exceptions (Active) is improved, it significantly predicts Effectiveness and Satisfaction but not Extra Effort.

In this research, descriptive statistics and regression analysis are used to find out how a leader who is most relevant in higher education institutions can increase the positive relationship of this leadership style with expected work results (performance), such as extra effort, effectiveness, satisfaction. Service and job satisfaction. The study concluded that the leadership style could predict the extra effort, effectiveness, and satisfaction of educators and education staff of FTIK IAIN Bukittinggi in full-scale and sub-scale modes.

Next, regarding performance, it is necessary to explain that performance results from desired behavior in carrying out a job. Mangkunegara (2016) says the term performance is related to the ability of an employee to maintain the quality and quantity of his work with good results where he responsibly manages to carry out the tasks assigned to him. Then the excellent quality and quantity in his work can be his self-reflector which shows that he has maximum competence. The Al paper shows that one of the factors in improving the performance of subordinates is the encouragement of the organization's leadership style. So with this encouragement, members and employees of the agency become motivated to work optimally. Because without these supporting factors, it is difficult for an employee to achieve and improve his performance. So it is concluded that one of the factors that can support and influence employee performance to be better is the leadership style factor.

Based on the research and data analysis that has been carried out, it can be concluded that the performance of educators and education staff at FTIK IAIN Bukittinggi can be predicted from the leadership style by using the equation or model above. It means that there is the linearity of the relationship between leadership style and the performance of educators and educational staff, namely when there is the excellent performance of educators and education staff, it can be predicted that the leadership style of leadership is also good, the otherwise poor performance of educators and education personnel can be predicted because of the leadership style FTIK IAIN Bukittinggi is not good either.

The results of the analysis above can be referred to the theory or concept of leadership style, one of which, according to Hasibuan (2016) states that the leadership style of a leader influences the performance of subordinates to influence, encourage, and direct subordinates 
so that subordinates or partners are willing to cooperate and productive in working together to achieve organizational goals.

Furthermore, in line with the expert's opinion above, the relationship between leadership style and employee performance, from the several works of literature, investigated, it is clear that there is a positive relationship between leadership and employee performance. Leadership style is recognized as being able to affect the performance of educators or education staff (the term two variants of employees in higher education) in achieving the goals (Himawan et al., 2019).

In the research conducted by Agung et al. (2021), the results of the calculation of the scale range are known that the average total score or the value of the Situational Leadership Style variables, which is 285.4 , is in the excellent category; this means that the leader being studied provides by the Main Tasks and Functions (TUPOKSI) of his subordinates by the structure and position (Job Distribution). The agency determines the composition of the persona then provides direction and control over the execution of the duties of its subordinates. The research description also explains how leaders provide discussion space for their subordinates to provide opportunities to express issues related to their work and, at the same time, as a method of paying attention to employee input.

Besides that, there is also a strengthening of this opinion with another opinion that leadership is a form of leadership power based on competence to encourage or motivate other people and members of the organization to make efforts to achieve institutional results. Of course, he requires a leadership attitude whose capacity to lead is beyond doubt. He can be accepted by the group in a rational, objective, and friendly manner while maintaining professionalism.

Furthermore, from the research on the relationship between work motivation and employee performance, As the results of Maryati et al. (2020) research on 108 elementary school teachers with the status of Civil Servants in Sembawa District, Banyuasin Regency, which shows that (1) Principals with their leadership style affect teacher performance by $50.7 \%$; (2) Then the teacher's performance is influenced by organizational culture by $48.2 \%$; and (3) Furthermore, the principal's leadership style and organizational culture simultaneously have a positive effect on teacher performance by $59.5 \%$ and others are influenced by other variables outside the study.

Based on the explanation above, the leadership style directly also influences the policies taken by the leadership and has an enormous influence on the universities they lead. Furthermore, the quality of work produced by their employees is also influenced by every policy issued. Therefore, the leadership style has a significant role in influencing how employees work; the appearance of the leadership style will positively or negatively impact the performance of the employees they lead. According to Afandi (2018), the Leadership style is a dynamic potential that motivates and coordinates organizational management to achieve 
goals. Furthermore, it can also be seen that the organizational leadership style is how the leader interacts with his subordinates,

Then, it was obtained from the results of the hypothesis testing carried out. The significance value of the relationship between the leadership style of the FTIK IAIN Bukittinggi leadership on the performance of educators and education is $0.003<0.05$. So it can be concluded that $\mathrm{HO}$ is rejected and $\mathrm{HI}$ is accepted, or there is a significant influence of leadership style on the performance of educators and education staff at FTIK IAIN Bukittinggi. The magnitude of the contribution or influence is $23.3 \%$; in other words, the leadership style can explain $23.3 \%$ of educators' and education performance.

Based on the results of this study, it is clear that leadership style has a significant influence on performance, so it can be suggested that to improve the performance of educators and education personnel, support from the leadership is needed. This research only looks at the effect of leadership style on performance, in general, to be developed to see more precisely what kind of leadership style has a significant effect on performance.

\section{CONCLUSION}

Based on the research that has been done, there is a good category of performance of lecturers and education staff of FTIK IAIN Bukittinggi. The ability of educators and education staff of FTIK IAIN Bukittinggi in achieving work results at the appointed time is one indicator of the success of the FTIK IAIN Bukittinggi leadership in leading and providing direction and guidance to educators and education personnel to appear as proactive and successful employees. In addition, leaders also need to provide encouragement or work motivation to employees or their subordinates because motivation at work has an equally vital role in increasing the carrying capacity of work quality.

Then it can be explained further that the performance of educators and education staff at FTIK IAIN Bukittinggi can be predicted from the leadership style by using the equation or model above. There is a linear relationship between leadership style and the performance of educators and education staff; namely, if the performance of educators and education personnel is good, it can be predicted that the leadership style of leadership is also good, and vice versa. From the linearity between leadership style and the performance of educators and education personnel of FTIK IAIN Bukittinggi, it is suspected that it will improve the quality of education services, higher education bureaucracy, and services to the higher education community in general. However, this needs further proof with further research that will be carried out by researchers in the following year and or maybe other researchers who are interested in proving it directly.

With the implementation of this research, the researchers would like to thank the academic community of FTIK IAIN Bukittinggi. The latter have been willing to become resource persons, respondents, or become a sample of the population of this study. Hopefully, the results 
of this study can provide a broad contribution to the development of knowledge about the management policies of the FTIK IAIN Bukittinggi educational institutions in particular, and universities in general, both those under the auspices of the Ministry of Religion and Higher Education.

\section{REFERENCE}

Afandi. P. (2018). Human Resource Management (theories, concepts and indicators). Yogyakarta: Zanafa Publishing.

Agung, A. D., Mohyi, A., \& Nurhasanah, S. (2021). The Effect of Leadership Style and Employee Satisfaction on Employee Commitment of UMM Hospital Malang. Jamanika (Jurnal Manajemen Bisnis Dan Kewirausahaan), 1 (1), 64-69.

Fraenkel, J.R. \& Wellen, N.E. (2008). How to Design and Evaluate Research in Education. McGraw-Hill.

Hasibuan. S.P. (2016). Human Resources Management Revised Edition. Jakarta: PT Bumi Aksara Himawan, I., Taba, I., \& Reni, A. (2019). The Effect of Leadership Style and Organizational Culture on Employee Performance Through Job Satisfaction as an Intervening Variable at Telkom Indonesia Regional VII Division. Hasanuddin Journal of Business Strategy, 1 (3), 37-50. https://doi.org/10.26487/hjbs.v1i3.252

Kadir, A. (2013). Tata Kelola Perguruan Tinggi di Era ITC. Shautut Tarbiyah, 19(1), 66-83.

Kebede, A. M., \& Demeke, G. W. (2017). The Influence of Leadership Styles on Employees' Job Satisfaction in Ethiopian Public Universities. Contemporary Management Research, 13(3), 165-176. https://doi.org/10.7903/cmr.17668

Mangkunegara. A.P. (2016). Company Human Resources Management. Bandung: PT Pemuda Rosdakarya.

Maryati, E., Fitria, H., \& Rohana, R. (2020). The Influence of Principal's Leadership Style and Organizational Culture on Teacher's Performance. Journal of Social Work and Science Education, 1 (2), 127-139. https://doi.org/10.52690/jswse.v1i2.38

Raffo, C., \& Gunter, H. (2008). Leading schools to promote social inclusion: Developing a conceptual framework for analyzing research, policy, and practice. In Journal of Education Policy. https://doi.org/10.1080/02680930801923799

Raja, A. S., \& Palanichamy, P. (2011). Leadership Styles and its Impact on Organizational Commitment. Asia Pacific Business Review. https://doi.org/10.1177/097324701 100700315

Sudarmanto. (2009). HR Performance \& Competency Development HR Performance \& Competency Development. Yogyakarta: Student Library.

Tampubolon, B. D. (2007). Analysis of Leadership Style Factors And Work Ethic Factors On Employee Performance In Organizations That Have Been Implemented. SNI 19. SNI 199001-2001. Journal of Standardization. No. 9. Hal: 106-115.

Wibowo. (2010). Organizational Culture Organizational Culture. Jakarta : Rajawali Press 
Yeo, R. K. (2020). Get ready to shift: Situational positioning of leadership identity and influence. Organizational Dynamics, 49(2). https://doi.org/10.1016/j.orgdyn.2018.11.001 